\title{
КОМПЕТЕНТНІСНИЙ ПІДХІД ЯК ЕЛЕМЕНТ АДАПТАЦІЇ ОСОБИСТОСТІ ІНОЗЕМНОГО СТУДЕНТА
}

\author{
YAROSLAV SLUTSKIY, \\ Candidate of Pedagogical Sciences \\ ЯРОсЛАВ СЛУЦЬКИЙ, \\ https://orcid.org/0000-0002-5328-7274 \\ yaroslav.slutskiy.mail@gmail.com \\ Donbas State College of Technology \\ and Management \\ $\triangle 3 a$ Ye.Sednieva St., \\ Toretsk, Donetsk region, 85200 \\ Донбаський державний коледж \\ технологій та управління \\ $\triangle$ вул. Є.Седнєва, За \\ м. Торецьк, Донецька обл., 85200
}

Original manuscript received: August 04, 2019

Revised manuscript accepted: September 21, 2019

\begin{abstract}
The article deals with the direct influence of social environment on the individual internal skills development, which contributes to its formation as a professional element of the modern labor market. Besides, the nature of the individuality, that lies in the complex of certain features is reviewed. Such features are used during the connection processes with the environment and the availability of interpersonal activity skills, which aimed on the communication process execution with other people. The foreign student during the interaction with the environment of studying country, is under the culture shock influence, that is why it is necessary to apply certain approaches that will promote to more effective socialization and integration into a new academic and socio-cultural environment. One of the main approaches is competence, which helps to create such personal skills that would facilitate to the possibility of implementation of the most qualitative built interpersonal and intercultural interaction.

The views of scholars of the term "competence approach» were considered, that helps to come to the definition as a individual opportunity to use the acquired competencies in the practice plane for solving certain problems and issues that have adaptive character. It was found that competent approach enables its using not only in the educational process at the university or college (that means the development of certain set of competencies, both theoretically and practically and also performing the analytical activity to detect probable errors in the preparatory programs and their further removal), but also after finishing the educational process, during the selection the candidates for certain positions.

The differences between the concepts "competency» and "competence» were investigated, that helps to come to the conclusion that competencies are the elements, which helps to carry out the certain type activity, in addition, the number of such formed elements may differ from the direction and complexity of activity. In turn, competence is
\end{abstract}


the ability of the individual to manage competencies in the process of academic or sociocultural activity.

Key words: competence, competency, personality, competence approach, educational (academic) process, socio-cultural activity .

Вступ. Глобалізаційні умови, які впливають на вищу освіту, демонструють необхідність визначення основних концепцій, що дозволяють розглянути систему соціально-педагогічного супроводу іноземних студентів. Тому для можливості проведення подальшого дослідження нам важливо визначення методології адаптаційної проблеми інтеграції особистості іноземного студента в нове для нього соціокультурне середовище.

Методи та методики дослідження. Методи та методики дослідження. Проблема соціалізації іноземного студента, формування навичок для його інтеграції у нове соціокультурне та академічне суспільство через призму компетентнісного підходу та його зв'язку 3 особливостями особистості є предметом наукових розвідок (В. Янчук, Н. Черниш, М. Корнєва, А. Коваленко, І. Бех, І. Зимня, Г. Селевко, А. Хуторський, М. Армстронг, Г. Данілова). Зупинимося на висновках В. Болотова, Дж. Равена, Н. Ничкало, які зазначали, що роль компетентнісного підходу не тільки в становленні та подальшому розвитку відповідних компетенцій особистості, а й у розумінні іноземним студентом своїх переваг та здатності ефективно ними управляти.

Результати та дискусії. Перш за все, нам необхідно зрозуміти, яким чином і чому соціум має значний вплив на особистість? Так, вкажемо на те, що саме поняття “особистість" та проблема особистості $€$ важливим компонентом багатьох наук, серед яких як психологічні, так i соціальні. Крім того, особистість за твердженням І. Кон - конкретний суб'єкт діяльності в єдності його індивідуальних властивостей і соціальних ролей, соціальна властивість індивіда, сукупність інтегрованих у ньому соціально значущих рис, що утворилися в прямій і непрямій взаємодії цієї особистості 3 іншими людьми і що сприяють становленню його суб'єктом роботи, пізнання і спілкування" (Бігуляк, 2013: 9-10). Таким чином, особистість має дві характеристики: перша визначає ії в конкретній людині, в якій сконцентровані одночасно як знання та вміння, що сприяють вмінню проводити різного роду діяльність, так і ролі соціального плану, які вона повинна використовувати при міжособистісному контакті. Стосовно другої вона визначає особистість не як центр концентрації сутнісних характеристик, а як одну 3 якостей людини, яка формується в процесі взаємодії з іншими людьми, що, у підсумку, трансформує її в суб'єкт, здатний до проведення міжособистісної, фрізичної та освітньої діяльності. Тобто, друга характеристика дає нам зрозуміти, що особистість не $є$ основою 3 певними навичками, а сама $€$ навичкою, до того ж такою, що має передумови до формування. Однак, якщо дещо розширити це визначення, не цілком зрозуміло, чи формується навички особистості в обов'язковому порядку або тільки за умови практичної взаємодії з іншими 
індивідами. Якщо відповідь позитивна, тоді чи можна говорити про ймовірність існування людини без наявності навички формування особистості. Тому наведене визначення не повністю дає розуміння суті поняття "особистість".

У свою чергу, В.Янчук прийшов до висновку, що "у структурі соціально-психологічного знання про особистість можна відштовхуватися від завдання розкриття структурної складності особистості, яка $є$ одночасно як об'єктом, так і суб'єктом суспільних відносин" (Янчук, 2000: 241). Відзначимо, що наведена характеристика заперечує можливість визначення особистості як одного з компонентів індивіда та вказує на те, що поняття може виступати як об'єктом, так і суб'єктом, що має на увазі наявність в особи структурованості, що робить її більш складним елементом, ніж просто навичка, яку можна сформувати. Більш складний характер особистості підтверджується висновком, що "для соціальнопсихологічного аспекту вивчення особистості продуктивними виявилися ідеї залежності особистості від впливу безпосереднього соціального оточення" (Янчук, 2000: 243). Якщо ми говоримо про наявність впливу навколишнього простору на особистість, то вже цей фактор демонструє складності поняття особистості, тому що проста навичка не може бути схильна до зовнішніх впливів. Якщо йдеться про особистість, на яку $є$ вплив, то в такому випадку ми можемо говорити про саму наявність навички в людини.

Згідно 3 фрілософським енциклопедичним словником, особистість визначається як "аспект внутрішнього світу людини, що характеризується унікальністю та відкритістю; реалізується в самопізнанні та самотворенні людини та об'єктивується в артефактах культури" (Шинкарук, 2002: 457). Таким чином, особистість виступає внутрішнім компонентом індивіда, що формується в залежності від культурних традицій. Наведене визначення дозволяє нам зробити висновок щодо неможливості сприйняття особистості як навички людини, що формується; це більш складний феномен, який $€$ частиною сутності індивіда. Філософський енциклопедичний словник також вказує, що "особистість витлумачується як соціальна маска індивідуальності" (Шинкарук, 2002: 258). Отже, особистість надає людині можливість демонструвати свою індивідуальність в соціумі. Це означає, що особистість може проявлятися у діях людини, спрямованих на взаємодію з навколишнім середовищем, що дозволяє говорити про особистість як елемент проведення міжособистісних контактів, іншими словами, діяльності соціального характеру. Таким чином, соціальна сутність особистості внутрішньою здатністю індивіда ефективно застосовувати компонент особистості в діяльності міжособистісного та міжкультурного характеру.

Зважаючи на те, що особистість є показником індивідуальності, радить Н. Черниш розглядати ії як щось "особливе і специфічне, що вирізняє одну людину з-поміж інших, включно з її природними і соціальними, фізіологічними і психічними, успадкованими і набутими якостями" (Черниш, 2003: 13). Отже, у зв'язку з тим, що індивідуальність $€$ 
похідним елементом особистості та включає в себе перераховані якості, можна стверджувати, що і особистість продукує в собі наведені якості і також безпосередньо впливає на психологічну, соціальну поведінку індивіда, тобто керує багатьма компонентами, які характеризують діяльність людини, що ще більшою мірою показує ії соціальну спрямованість.

Соціальна сутність феномену особистості також підтверджується висновками М. Корнєва та А. Коваленко, які визначали особистість як "стійку систему соціально-значущих рис людини, зумовлених ії залученням до системи суспільних відносин, сформованих у процесі спільної діяльності та спілкування з іншими людьми" (Корнєв, Коваленко, 1995: 235). Як ми бачимо, вчені також розглядають особистість як комплекс рис та якостей, що також відкидає розуміння особистості як навички, що схильна до формування. Стосовно ії соціальної сутності, вона проявляється в тому числі, в міжособистісній комунікаційній діяльності, яка дозволяє вибудувати взаємини з іншими індивідами. Таким чином, особистість ґрунтується на необхідності соціального контакту з іншими людьми, більше того, вона є провідником між соціумом та індивідом, виступаючи елементом, що дозволяє виконувати соціальні функції.

Однак особистість не зможе проводити ефрективну соціальну взаємодію, якщо індивід не буде володіти спеціальними навичками, які формуються і розвиваються для виконання того чи іншого виду діяльності. У разі відсутності такого роду навичок людина втрачає якість професіоналізму, що не дозволяє в тому числі проводити саморозвиток. Тому розуміння сутності цих якостей має визначальне значення в дослідженні методології соціально-педагогічного супроводу, яке і спрямоване на фрормування необхідних навичок, що дозволять адаптуватися до нового культурного середовища. Таким чином, ми повинні розглянути підходи, кожен з яких $\epsilon$ елементом системи соціально-педагогічного супроводу. Одним з них ми можемо визначити компетентнісний підхід, як необхідна складова адаптації іноземного студента.

Однак перш ніж давати характеристику компетентнісного підходу, необхідно визначитися з розумінням компетентності. Так, І. Бех вказує, що "трактування поняття компетентність дуже широке..." (Бех, 2009: 5). Дійсно, не можна трактувати поняття компетентності як будь-який індивідуальний елемент професіоналізму людини у зв'язку з тим, що компетентність - це комплекс різних навичок, які, взаємодіючи, під час виконання практичної діяльності надають можливість виконання профресійних дій.

Необхідно відзначити, що інтерес до дослідження компетентнісного підходу виник у вчених відносно недавно. Так, І. Зимня визначає найбільш значущі етапи розвитку компетентнісного підходу в педагогіці, психології та соціології. Відповідно до твердження автора існує три етапи: перший (1960-1970) показує часовий проміжок, в період якого було розпочато використання в науці терміну "компетенція", а також 
виникли умови для подальшого пояснення існуючої відмінності між "компетенцією" та "компетентністю"; другий (1970-1990рр.) характеризується активним уживанням обох понять як в науковому середовищі, так і при описі якісного рівня спеціаліста; третій - має точкою відліку 1990 рік і виділяє дослідження компетентності як окремої категорії (Зимня, 2003).

Дослідники характеризують компетентнісний підхід по-різному. Так, Г. Селевко приходить до висновку, що "компетентнісний підхід означає поступову переорієнтацію домінуючої освітньої парадигми 3 переважною трансляцією знань, формуванням навичок створення умов для оволодіння комплексом компетенцій, що означають потенціал, здатність випускника до виживання і стійкої життєдіяльності в умовах сучасного багаточинникового соціально-політичного, ринковоекономічного, інформаційно і комунікаційно насиченого простору" (Селевко, 2004: 138). Тобто, такий підхід передбачає трансформацію освітнього аспекту особистості 3 упровадженням та подальшим використанням нових навичок - компетенцій, спрямованих на підвищення конкурентоспроможності особистості в сучасних умовах. У свою чергу, В. Болотов вказує, що компетентнісний підхід ставить основною метою не "інформованість учня, а вміння вирішувати проблеми" (Болотов, 2003: 10). Таким чином, основним завданням компетенцій $€$ не надання студенту інформаційної складової про отримувані можливості та умови застосування таких навичок, тобто не теоретичний компонент, а безпосереднє практичне застосування компетенцій, навчання їх використання для вирішення тактичних та стратегічних проблемних ситуацій, що мають адаптаційну природу. У разі, якщо йдеться не про процес адаптації як такої (коли об'єктом виступає іноземний студент), а просто формування навичок виконання певної діяльності, ми також можемо говорити про адаптацію, тому що в такому випадку розглядається внутрішньо-культурна адаптація, тобто пристосування до проведення комунікаційної та міжособистісної взаємодії, перебуваючи при цьому у своїй культурі. Отже, компетентнісний підхід може бути використаний не тільки при адаптаційної діяльності класичного характеру, у якій відбувається поєднання представників різних культур.

Інтерес представляють висновки Дж. Равена, який виділив причини, що сприяють застосуванню компетентнісного підходу в освітньому процесі. Так, автор висловлює думку, що цей підхід повинен застосовуватися, щоб учні мали можливість визначення своїх якісних сутнісних характеристик, подальшого їх розвитку та проведення аналізу (для виявлення можливостей поліпшення); викладачі мали можливість проведення контролюючої діяльності за якістю виконання затвердженого індивідуального плану розвитку навичок; проводилися діагностичні заходи, спрямовані на виявлення негативних аспектів підготовчих програм та подальше їх вдосконалення з боку відповідальних осіб; була отримана можливість виявлення найбільш професійно придатних фахівців для діяльності в тому чи іншому напрямку при організації набору 
фахівців на вакантні робочі посади, враховуючи практичний рівень володіння ними необхідними компетенціями (Равен, 1999: 65-66). Таким чином, ми можемо прийти до висновку, що компетентнісний підхід має більш широке застосування: не тільки в рамках освітнього процесу (що передбачає теоретичний та практичний розвиток певного набору компетенцій, а також проведення різних діагностичних заходів, що дозволяють виявити існуючі недоліки в підготовчих програмах і сприяти їх усуненню), але і після закінчення закладу освіти, при відборі кадрів на певні посади (що має на увазі розгляд кандидатів з точки зору наявності у них здібностей та досвіду застосування тих компетенцій, які необхідні для конкретного виду діяльності).

Відзначимо, що компетентнісний підхід передбачає наявність таких аспектів індивіда, як компетенції, які, у свою чергу, мають різні характеристики. Так, Тлумачний словник чужомовних слів в українській мові дає визначення, що компетенція - це "добра обізнаність із чимнебудь" (Сліпушко, 1999: 235). Отже, компетенція передбачає, перш за все, отримання індивідом достатньої кількості теоретичних знань щодо конкретного напрямку. Одночасно, якщо ми розглядаємо компетенції в компетентнісному підході, виникає питання щодо поняття "компетентності", яка, за думкою одних учених (Хуторський, 2003), має відмінності від компетентності та є їі частиною; інших - характеризується в залежності від внутрішніх особливостей індивіда та рівня його навичок, у той час як компетентність визначається якістю загального кваліфікаційного рівня особистості (Недашківська, 2008: 70). Отже, ми приходимо до висновку про те, що компетентність $є$ більш широким значенням, ніж компетенція. Звернемо увагу на висновки М. Армстронг, у яких компетенція визначається показником професіоналізму особистості в контексті проведення нею будь-якої діяльності, у той час як компетентність характеризується визначенням особистості, в тому числі її професійних та поведінкових рис (Армстронг, 2004: 272-273). Таким чином, компетенції $є$ навичками, що надають допомогу у виконанні певної діяльності, до того ж, кількість цих навичок може відрізнятися в залежності від складності дій, які необхідно виконати, а компетентність забезпечує вміння управляти комплексом компетенцій у процесі діяльності. Вкажемо також на інші висновки дослідників. Так, Г. Данілова зазначає, що компетентність - це "...здатність приймати рішення і нести відповідальність за їх реалізацію при виконанні функціональних обов'язків" (Данилова, 1995: 10). Тобто, вміння приймати рішення про використання тієї чи іншої компетенції в конкретний момент і є проявом здатності керувати своїми навичками. У свою чергу, Н. Ничкало вказує, що компетентність - це "...не тільки професійні знання, навички і досвід у спеціальності, але і ставлення до справи, визначені (позитивні) схильності, інтереси і прагнення, здатність ефективно використовувати знання й уміння, а також особистісні якості для забезпечення необхідного результату на конкретному робочому місці в конкретній робочій ситуації" (Ничкало, 2002: 96). Таким чином, компетентність необхідно розглядати 
не тільки як застосування комплексу компетенцій, а й наявності в індивіда внутрішніх характеристик, що забезпечують професійну діяльність, зокрема самоконтроль, самоаналіз, саморозвиток. Однак наведені характеристики також $є$ компетенціями, тому ми повертаємося до висновку про те, що компетентність $\epsilon$ умінням ефективно використовувати сформовані навички на практиці.

Висновки. Розглянувши категорії компетенції та компетентності, ми приходимо до висновку, що вони як складові компетентнісного підходу безпосередньо впливають на професійну компетентність фахівця. Таким чином, компетентнісний підхід - це формування в особистості студента теоретико-практичних навичок (психологічного, лінгвістичного, соціокультурного характеру), які сприяють ефективному проведенню міжособистісної та міжкультурної діяльності. На жаль, перебування в новому академічному та соціокультурному середовищі передбачає необхідність вирішення також і культурних проблем, що виникають у зв'язку із впливом культурного середовища. Тому компетентнісний підхід має бути пов'язаним з культурологічним, який має стати продовженням наукових розвідок проблеми адаптації іноземного студента.

\section{Література}

1.Армстронг М. Практика управления человеческими ресурсами / М. Армстронг; [пер. с англ. Е.Бугаевой; под общ. ред. С.К. Мордовина]. - 8-е изд. Спб.: Питер, 2004. - 832 с.

2.Бех І.Д. Теоретико-прикладний сенс компетентнісного підходу у педагогіці.— К.: Виховання і культура №12 $(17,18)-2009$ р.- C.5-7.

3.Болотов В. А., Сериков В. В. Компетентностная модель: от идеи к образовательной программе // Педагогика.- 2003.- № 10.- С. 8-14.

4.Данилова Г. С. Управління процесом становлення професійної компетентності методиста.- К.: УІПКККО, 1995.- 80 с.

5.Державні стандарти професійної освіти: теорія і методика: Монографія / За ред. Н. Г. Ничкало.- Хмельницький: ТУП, 2002.- 334 с

6.Зимняя И. А. Ключевые компетенции - новая парадигма результата образования // Высшее образование сегодня.- 2003.- № 5.- С. 34-42.

7. Корнєв М. Н. Соціальна психологія / М. Н. Корнєв, А. Б. Коваленко. - К. : Наукова думка, 1995. - 237 с.

8. Недашківська Т. Професійність державних службовців: компетентнісний підхід / Т. Недашківська // Зб. наук. пр. Нац. акад. держ. упр. при Президентові України / [редкол. : Оболенський О.Ю., Сьомін С.В. та ін.]. - К.: Вид-во НАДУ, 2008. - Вип.1. - С.65-74.

9.Равен Дж. Педагогическое тестирование: Проблемы, заблуждения, перспективы / Пер. с англ.- М.: КогитоЦентр, 1999.- 144 с.

10. Селевко Г. Компетентности и их классификация // Народное образование.- 2004.- № 4.- С. 138-143

11. Сліпушко О.М. Тлумачний словник чужомовних слів в українській мові. Правопис. Граматика / О.М. Сліпушко. - К.: Криниця, 1999. - 507 с.

12. Філософський енциклопедичний словник / під ред. В. Шинкарук. - К.: Абрис, 2002. - 742 с.

13. Хуторской А.В. Ключевые компетенции как компонент личностноориентированной парадигмы образования / А.В. Хуторской // Народное образование, 2003. - № 2. - С. 58-64. 
14. Черниш Н. Соціологія / Н. Черниш. - Львів : Кальварія, 2003. - 474 с.

15. Янчук В.А. Методология, теория и метод в современной социальной психологии и персонологии: интегративно-эклектический подход. - Мн.: Бестпринт, 2000. -416 с.

16. Бігуляк О.О. Соціальна сутність особистості та іï формовияви / О.О. Бігуляк. - Тернопіль, 2013. - 98 с.

\section{References}

1. Armstrong, M. (2004). Praktika upravleniya chelovecheskimi resursami [The practice of of personal resources management]. Saint-Petersburg, 832 p. [in Russian].

2. Bekh, I.D. (2009). Teoretyko-prykladnyi sens kompetentnisnoho pidkhodu u pedahohitsi [Theoretical and applied meaning of competence approach in pedagogy]. Education and culture. Kyiv, No.12 (17,18), pp.5-7. [in Ukrainian].

3. Bolotov, V. A., Serikov, V. V. (2003). Kompetentnostnaya model: ot idei k obrazovatelnoy programme [Competence model: from idea to the educational program]. Pedagogy. No.10, pp.8-14. [in Russian].

4. Danylova, H. S. (1995). Upravlinnia protsesom stanovlennia profesiinoi kompetentnosti metodysta [The management of the process of professional methodologist competence formation]. Kyiv, 80 p. [in Ukrainian].

5. Nychkalo, N. H. (2002). Derzhavni standarty profesiinoi osvity: teoriia metodyka [The State standards of professional education: theory and methodology]. Khmelnytskyi, 334 p. [in Ukrainian].

6. Zimnyaya, I. A. (2003). Klyuchevye kompetentsii - novaya paradigma rezultata obrazovaniya [A key competencies - the new paradigm of educational result]. Higher education today. No.5, pp.34-42. [in Russian].

7. Korniev, M. N. (1995). Sotsialna psykholohiia [Social psychology]. Kyiv, 237 p. [in Ukrainian].

8. Nedashkivska, T. (2008). Profesiinist derzhavnykh sluzhbovtsiv: kompetentnisnyi pidkhid [Professionalism of State employees: competence approach]. Journal of Research of the National Academy for Public Administration under the President of Ukraine. Vol.1, pp.65-74. [in Ukrainian].

9. Raven, Dzh. (1999). Pedagogicheskoe testirovanie: Problemy, zabluzhdeniya, perspektivy [Pedagogical testing: Problems, mistakes, perspectives]. Moscow, 144 p. [in Russian].

10. Selevko, G. (2004). Kompetentnosti i ikh klassifikatsiya [Competencies and their classification]. People's Education. No.4, pp.138-143. [in Russian].

11. Slipushko, O.M. (1999). Tlumachnyi slovnyk chuzhomovnykh sliv $v$ ukrainskii movi. Pravopys. Hramatyka [Explanatory dictionary of foreign words in Ukrainian language. Spelling. Grammar]. Kyiv, 507 p. [in Ukrainian].

12. Shynkaruk, V. (2002). Filosofskyi entsyklopedychnyi slovnyk [Philosophical encyclopedic dictionary]. Kyiv, 742 p. [in Ukrainian].

13. Khutorskoy, A.V. (2003). Klyuchevye kompetentsii kak komponent lichnostnoorientirovannoy paradigmy obrazovaniya [The key competencies as a component of personal oriented paradigm of education]. People's Education. No.2, pp.58-64. [in Russian].

14. Chernysh, N. (2003). Sotsiolohiia [Sociology]. Lviv, 474 p. [in Ukrainian].

15. Yanchuk, V.A. (2000). Metodologiya, teoriya $i$ metod $v$ sovremennoy sotsialnoy psikhologii i personologii: integrativno-eklekticheskiy podkhod [Methodology, theory and method in modern social psychology and personology: integrative and eclective approach]. Minsk, 416 p. [in Russian].

16. Bihuliak, O.O. (2013). Sotsialna sutnist osobystosti ta yii formovyiavy [The social essence of a person and its forms]. Ternopil, 98 p. [in Ukrainian]. 


\section{АНОТАЦІЯ}

У статті проаналізовано безпосередній вплив соціального оточення на розвиток внутрішніх навичок особистості, які сприяють ї̈ формуванню як професійного елемента сучасного ринку праці. Крім того, розглянута природа особистості, що криється в комплексі певних рис іноземного студента, що використовуються при взаємодії з навколишнім середовищем, та наявності навичок міжособистісної діяльності, яка спрямована на виконання комунікативного процесу з оточуючими особистостями. У зв'язку з тим, що іноземний студент при взаємодії з оточенням перебуває під впливом культурного шоку, необхідно застосування певних підходів, які сприятимуть більш ефективній соціалізації та інтеграції до нового академічного та соціокультурного середовища. Одним $з$ основних підходів є компетентнісний, що дозволяє сформувати такі особистісні навички, які б сприяли можливості проведення найбільщ якісно вибудуваної міжособистісної та міжкультурної взаємодії.

Розелянуто погляди вчених щодо терміна "компетентнісний підхід", що дозволило прийти до власного визначення поняття як можливості індивіда використовувати набуті компетенції в практичній площині для вирішення тих чи інших проблем та питань адаптаційного характеру. Виявлено, що компетентнісний підхід надає можливість його використання не тільки в рамках освітнього процесу в університеті або коледжі (що стосується розвитку певного набору компетенцій, як в теоретичному, так і в практичному плані, а також виконання діяльності аналітичного характеру з виявлення ймовірних помилок у підготовчих програмах та подальшому їх усуненню), а й по завершенню освітнього процесу, при відборі кандидатів на певні посади.

Досліджено відмінності між поняттями "компетенція" та "компетентність", що дозволило прийти до висновку, що компетенції $\epsilon$ елементами, які надають допомогу при проведенні діяльності певного типу, крім того, кількість таких сформованих елементів може відрізнятися від направленості та складності ймовірної діяльності. У свою чергу, компетентність представлена у якості спроможності особистості проводити управління компетенціями у процесі проведення академічної або соціокультурної діяльності.

Ключові слова: компетенція, компетентність, особистість, компетентнісний підхід, освітній (академічний) процес, соціокультурна діяльність. 